Click www.researchjournal.co.in/online/subdetail.html to purchase.

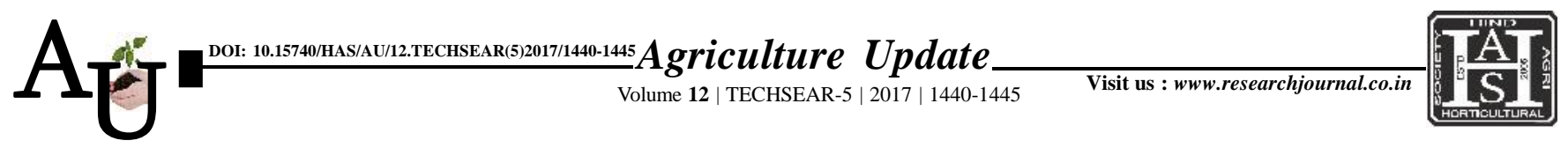

\title{
Research Article: In vitro efficacy of various seed dresser on seed mycoflora of safflower
}

\author{
V.M. GHOLVE, S.B. GHUGE, S.V. PAWAR AND P.T. BARDE
}

Article Chronicle:

Received :

15.07.2017;

Accepted :

30.07.2017

Key Words:

Seed mycoflora, Seed dresser, Alternaria

carthami, Fusarium

carthami,

Macrophomina

phaseolina, Safflower
SUMMARY : Seeds play vital role for the healthy production of crop and they are known to carry pathogens which cause poor seed health. Safflower (Carthamus tinctorius L.) occupies prominent place in the agricultural wealth and economy of the country. Safflower being rich source of proteins and edible oil has focused attention of farmers. Studies on seed mycoflora have greatly increased in the recent past in view of their importance as diseases carriers, deteriorating agents and also as toxin produces. In vitro efficacy of various seed dresser fungicides (systemic and non systemic) on the seed mycoflora improving per cent seed germination, seedling vigour, per cent seedling mortality and per cent infection. It was observed that maximum seed infection with $A$. carthami was recorded in treatment Thiram + Carbendazim $(10.50 \%)$ and minimum seed infection with M. phaseolina Thiram + Mancozeb $(0.00 \%)$, respectively. Effect of nine seed dresser fungicides on the per cent seedling vigour during the studies it was observed that fungicides improving the per cent seedling vigour and reducing per cent seedling mortality by rolled towel paper method. Maximum per cent of seedling vigour observed in Thirum + Mancozeb $(16 \%)$ and minimum per cent of seedling vigour observed in treatment Thiram+ Carbendazim (13\%). In per cent seedling mortality the there was no mortality observed in 24 and $48 \mathrm{hrs}$. The lowest per cent seedling mortality was observed in seed treatment Thirum + Mancozeb (5.5\%) and maximum per cent in the Thirum + Carbendazim (10.9\%) at $72 \mathrm{hrs}$.

How to cite this article : Gholve, V.M., Ghuge, S.B., Pawar, S.V. and Barde, P.T. (2017). In vitro efficacy of various seed dresser on seed mycoflora of safflower. Agric. Update, 12(TECHSEAR-5) : 1440-1445; DOI: 10.15740/HAS/AU/12.TECHSEAR(5)2017/1440-1445.
Author for correspondence :

\section{V.M.GHOLVE}

Department of Plant Pathology, Vasantrao Naik Marathwada Krishi Vidyapeeth, PARBHANI (M.S.) INDIA

Email : vikramgholve@ rediffmail.com

See end of the article for authors' affiliations 